\title{
Sanction plans anger Japan
}

\section{Washington \& Tokyo}

THE promise of tough action by the US Congress against the Japanese Toshiba group and the Norwegian company Kongsberg Vaapenfabrikk has evoked a strong protest from Japan, which fears that US attempts to police world technology will encroach on its independence.

Toshiba Machine Company and Kongsberg Vaapenfabrikk drew US anger by transferring advanced propellor milling machinery, developed in Japan, to the Soviet Union in defiance of regulations set by COCOM, the 16-nation Coordinating Committee for East-West Trade Policy set up to stem the flow of strategically sensitive goods to communist countries.

Both companies have been punished by their own governments. Toshiba Machine being hit by a one-year ban on sales to communist countries that will lose it around $\$ 40$ million. Now there is a possibility that they will be punished further by the US government, which Japanese and European diplomats complain will violate the sovereignty of COCOM countries and set an unwelcome precedent.

The punishment is proposed in the much-debated omnibus trade bill, which is finally in a form that both House of Representatives and Senate committees agree upon. If it is voted into law it will ban for three years all sales in the United States by both Toshiba Machine Company and Kongsberg Vaapenfabrikk. The Japanese parent corporation, the giant Toshiba Electronics Corporation, will also be punished with a three-year ban on sales to US government agencies. That ban could cost Toshiba Corporation alone some $\$ 100$ million a year.

Japan's International Trade and Industry Minister, Hajime Tamura, described the congressional measure as "foolish" and harshly rebuked US attempts to undermine the basic COCOM philosophy that each member nation should impose export controls voluntarily.

The bill provides a 2-5-year ban on US imports from companies that offend against COCOM regulations, whatever country they are located in. And it provides a retroactive punishment for those that have offended in the past, if they are linked to the Toshiba case. French and West German firms are under suspicion.

The trade bill contains several measures that offend US President Ronald Reagan, among them the punishment for Toshiba Corporation, and a presidential veto has been threatened if the bill passes through Congress without revision. Action on the bill in the House of Representatives is expected to begin this month.

Alun Anderson \& David Swinbanks

Soviet and US scientists go for a blast in the Nevada desert

Washington

THERE are unusual goings-on in the Nevada desert. Earlier this year, the US Department of Energy hosted a team of Soviet scientists at the highly secure Nevada Test Site where the United States tests its nuclear weapons (see Nature 331 , $380 ; 1988)$. Now another group of scientists from the Soviet Institute of Physics of the Earth will join US colleagues to detonate two chemical explosions at the site as part of an initiative sponsored by the

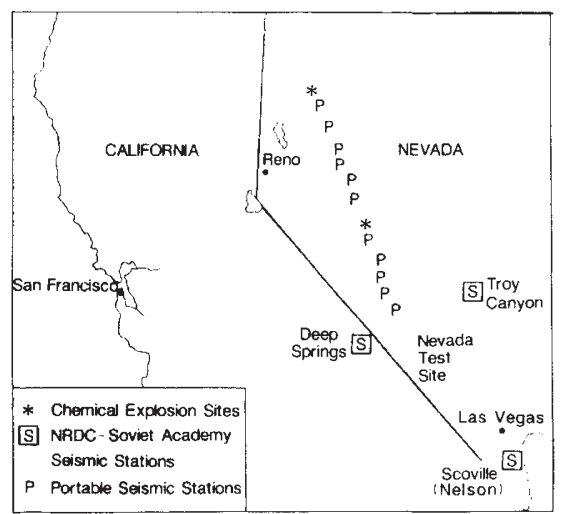

Natural Resources Defense Council (NRDC) and the Soviet Academy of Sciences to demonstrate technology for verifying a nuclear test-ban treaty.

The Soviet team, led by Senior Staff Scientist Nicolai Yukhnin of the Institute of Physics, arrived in the United States last week. They brought with them 1 ton of recording equipment to supplement the seismic monitoring devices already at the three NRDC-Soviet Academy stations located in Nelson, Nevada, Troy Canyon, Nevada, and Deep Springs, California, on the Nevada border (see map).

According to current schedules, 10 tons of chemical explosives will be set off on 29 April at Black Rock Desert, and 15 tons will be detonated the following day at Broken Hills. Portable seismic stations will be set up to record the waves after the explosion. In both cases the land is owned by the US government.

The NRDC and the Soviet Academy first agreed to establish seismic monitoring stations around the Soviet and US nuclear tests sites in May 1986 (see Nature 321, 638; 1986). The first stations were placed in the Soviet Union in September 1986 about $200 \mathrm{~km}$ from the Kazakhstan test site and the US stations were established the following winter. Last September, the Soviet Academy detonated three chemical explosions at the Kazakhstan test site. Based on seismic data collected from those explosions, NRDC reckons some 25 stations in the Soviet Union and 15 in neighbouring countries would be needed to verify compliance with a treaty that limited underground nuclear test yields to one kiloton.

This is the fourth time Soviet scientists have visited the United States as part of the NRDC-Soviet Academy activities, but it is the first time that the State Department has not placed restrictions on their travel. A State Department official refused to characterize the unrestricted visas as representative of any change in US policy.

\section{Evolutionary ships passing in the night?}

\section{Oxford}

OxFORD University's Sheldonian Theatre was the venue for a piece of real theatre on Saturday when Richard Dawkins and Stephen Jay Gould held a "Darwinian Dialogue".

Gould revels in pluralist approaches to explaining organic diversity. He argues for a hierarchical view of life, with selection acting in the emergent properties at each level of the hierarchy and sorting the units at other levels. It may be unsatisfactory to interpret speciation rates just as properties of genes. Gould also stresses the importance of developmental constraints and historical contingencies, like mass extinctions or selection for one trait (such as brain size) resulting in many non-adaptive epiphenomena (like Bach's B-minor mass).

Dawkins, on the other hand, is a selfprofessed monist fascinated by organized adaptive complexity, who focuses on the gene as the unit of selection. He coun- ters Gould's hierarchical view by distinguishing between replicators and vehicles. Genes, he argues, are the only true replicatros. Dawkins concedes that the evolution of evolvability is another problem that interests him. Some embryologies may have become more widespread because they permit a wider range of phenotypic possiblities and so are good at evolving. $\mathrm{He}$ cites segmentation as an example.

Both started by proclaiming a dialogue rather than a debate since, as Gould pointed out, truth is only one of many weapons in a debate. After separate 30. minute presentations, the dialogue (or was it a debate?) started. Nothing was resolved. Whether gene versus organismal selection is a matter of semantics (Dawkins) or not (Gould) remains an open issue. But it was not clear, to us at least, whether they were attempting to answer the same question. Nonetheless it was all jolly good fun.

Andrew Pomiankowski \& Paul H. Harvey 